\title{
Microscale patchiness of bacterioplankton assemblage richness in seawater
}

\author{
Richard A. Long*, Farooq Azam \\ Marine Biology Research Division, Scripps Institution of Oceanography, University of California, San Diego, La Jolla, \\ California 92093-0202, USA
}

\begin{abstract}
We sought to test the hypothesis that bacterial species richness and composition vary at the millimeter scale in the marine pelagic environment, in response to the heterogeneous distribution of organic matter. To test this hypothesis, it was necessary to design and test a protocol to sample, lyse and analyze (by polymerase chain reaction/denaturing gradient gel electrophoresis [PCR-DGGE]) bacterioplankton species richness in a single microliter of seawater. Significant variation in bacterial species richness was found amongst $1 \mu \mathrm{l}$ samples. Greater species richness was seen when seawater was enriched with diatom detritus. Examination of species richness at $2 \mathrm{~mm}$ intervals over a $20 \mathrm{~mm}$ transect showed greater variability during the peak abundance of Lingulodinium polyedrum when compared to the late stage of the bloom. Overall species richness was highest in samples enriched with organic particles. These results suggest that particulate organic matter may, in part, regulate the level of bacterial species richness as well as cause patchiness in the small-scale distribution of species. Microscale patchiness of bacterial species may have important implications in carbon cycling and biogeochemistry, not only at the microscale but also at the ocean basin scale.
\end{abstract}

KEY WORDS: Species richness $\cdot$ Diversity $\cdot$ Lyse-N-Go ${ }^{\mathrm{TM}} \cdot$ DGGE $\cdot$ Community structure Resale or republication not permitted without written consent of the publisher

\section{INTRODUCTION}

Heterotrophic bacteria exert a major influence on the structure and the dynamics of pelagic marine ecosystems through their interactions with organic matter (Azam 1998). They utilize highly variable but often large fractions of organic matter introduced by in situ primary production (Cole et al. 1988, del Giorgio \& Cole 1998) or by sinking particles (Cho \& Azam 1988, Turley \& Stutt 2000). Measurements of bacterial carbon demand over the last 2 decades have described the spatial-temporal variability of bacteria-mediated carbon fluxes in order to constrain ocean basin-scale biogeochemical models (e.g. Ducklow \& Fasham 1992). However, these models lack predictive capability. It has been suggested that our capability to predict the role of bacteria in the regulation of nutrient and organic matter fluxes would be enhanced if we could gain mechanistic understanding of how bacteria inter-

*E-mail: ralong@ucsd.edu act with the organic matter field and with what ecosystem consequences (Azam 1998 and references therein). Since bacteria interact with organic matter at micrometer to millimeter scales, we need, then, to understand the consequences of bacteria-organic matter interactions at such scales.

It has often been assumed that bacteria and their organic substrates are homogeneously distributed in seawater (but see Bell \& Mitchell 1972 and Azam \& Ammerman 1984 for an opposing view). So, bulk phase samples of a few milliliters to few tens of milliliters would be representative of microscale processes. However, it now appears that organic matter in seawater is distributed heterogeneously (Alldredge et al. 1993, Azam et al. 1993, Long \& Azam 1996), and some of it may constitute a hydrogel (Azam 1998, Chin et al. 1998). Bacteria might respond behaviorally to the microscale structure of the organic mater field and to nutrient gradients (Mitchell et al. 1996, Azam 1998). Hypothesized or inferred mechanisms causing nonrandom distribution of bacteria at the microscale in- 
clude clustering (Azam \& Ammerman 1984, Blackburn et al. 1998), attachment to algae or detritus (Biddanda \& Pomeroy 1988, Smith et al. 1995) and interactions with the gel particle matrix (Alldredge et al. 1993, Long \& Azam 1996). Indeed, one might even envision the formation of monospecific microcolonies of bacteria at specific organic matter loci in seawater (J. W. Ammerman et al. unpubl.).

There are potentially profound biogeochemical implications of microscale variations in bacterial abundance or bacterial composition, diversity and richness. While a few studies have tested for microscale variation in bacterial abundance, there has been no direct examination of bacterial community richness at the microscale level in the ocean. Bacterial counts in microliter samples have been used to test for variations in abundance. Duarte \& Vaque (1992) found a 2.5-fold variation, while Mitchell \& Fuhrman (1989) found 3.5-fold variation over a centimeter scale. However, MullerNiklas et al. (1996) detected no significant variation amongst $100 \mathrm{nl}$ samples. Seymour et al. (2000) took $50 \mathrm{\mu l}$ seawater samples $4.5 \mathrm{~mm}$ apart from each other. They found unstirred samples to have low variation but a 16-fold variation was observed if seawater was stirred prior to sampling. They attribute this difference to turbulent flows that spatially structure bacteria populations as well as to the interaction of bacteria with the gel particle matrix. No previous study has tested the hypothesis that microscale variations in species richness and patchiness exist in seawater. The goal of this study was to test the hypothesis that microscale variation in bacterial species richness and composition occurs in the pelagic marine environment, and further that the concentration of particulate organic matter (POM) loci regulates bacterial species patchiness.

The determination of 16S rRNA gene diversity in community DNA is a powerful tool, which has been extensively applied to examine spatial and temporal variations in species richness of Bacteria and Archaea in aquatic environments (for a review, see Giovannoni \& Rappè 2000). However, current protocols (Fuhrman et al. 1988, Somerville et al. 1989) rely on extracting DNA from 1 to 401 seawater, and are not suitable for microliter samples of interest here. In addition, these protocols involve multiple steps that lead to substantial DNA losses. As a first step towards our goal, it was thus necessary to design and test a protocol that enables the analysis of 16S rRNA gene richness and diversity from a single microliter of seawater. We have designed and tested a simple and reliable protocol in which such a minute seawater sample is extracted and subjected to polymerase chain reaction (PCR) amplification of $16 \mathrm{~S}$ rRNA gene fragments. (Our protocol is based on Lyse$\mathrm{N}-\mathrm{Go}^{\mathrm{TM}}$ [Pierce, Rockford, IL, USA] a commercially available reagent used on non-marine bacterial and fungal isolates.) All steps are performed in a single tube. Extracted DNA was amenable to PCR amplification and subsequent community structure analysis with denaturing gradient gel electrophoresis (DGGE). The method was used to test for small-scale patchiness of bacterial species in near-shore seawater samples and the response of patchiness to increased POM.

\section{MATERIALS AND METHODS}

Cell lysis and PCR amplification: cultured bacteria. Sixty bacterial isolates previously obtained from coastal marine pelagic environments were tested. They included bacteria isolated from seawater fractions operationally defined as attached or free. They were grown on ZoBell plates (each liter contained $15 \mathrm{~g}$ agar, $5 \mathrm{~g}$ peptone and $1 \mathrm{~g}$ yeast extract, dissolved in seawater that had been filtered through a Whatman GF/F filter). After $2 \mathrm{~d}$ incubation at room temperature $\left(20^{\circ} \mathrm{C}\right)$ colonies were carefully lifted to avoid picking up agar and transferred to microcentrifuge tubes with $1 \mathrm{ml}$ of $0.2 \mu \mathrm{m}$ filtered autoclaved seawater (FASW). The cells were vortexed to disperse them and then washed once (centrifuged; supernatant discarded; cells resuspended in FASW). They were then incubated at room temperature for $72 \mathrm{~h}$, to acclimate bacteria to low nutrient conditions.

The bacterial isolates were diluted to 10-100 cells $\mu^{-1}$; these concentrations were deemed representative of single species abundance in the natural assemblage, (i.e. a single species constituting 1 to $10 \%$ of the population). One microliter bacterial suspensions (containing 10 to 100 cells) were transferred to a clean thinwalled PCR tube. Five microliters of Lyse- $\mathrm{N}-\mathrm{Go}^{\mathrm{TM}}$ was added to the PCR tube and the thermocycling protocol for lysis was carried out according to the manufacturer's instructions $\left(65^{\circ} \mathrm{C} / 30 \mathrm{~s}, 8^{\circ} \mathrm{C} / 30 \mathrm{~s}, 65^{\circ} \mathrm{C} / 90 \mathrm{~s}\right.$, $97^{\circ} \mathrm{C} / 180 \mathrm{~s}, 8^{\circ} \mathrm{C} / 60 \mathrm{~s}, 65^{\circ} \mathrm{C} / 180 \mathrm{~s}, 97^{\circ} \mathrm{C} / 60 \mathrm{~s}, 65^{\circ} \mathrm{C} / 60 \mathrm{~s}$, $80^{\circ} \mathrm{C} /$ hold until the addition of $\mathrm{PCR}$ reagents).

To validate that the Lyse-N-GoTM protocol was effective, a $\sim 1460$ base pair (bp) segment of the 16S rRNA gene was amplified by a modification of the touchdown PCR protocol (Don et al. 1991). Upon completion of the lysis cycle, $44 \mu \mathrm{l}$ of a PCR master mix (2 U of Qiagen Taq DNA polymerase, $1 \mu \mathrm{M}$ of each primer, $0.8 \mathrm{mM}$ deoxynucleotide triphosphate [dNTP], final) was added to the tube and a touchdown PCR was performed using the universal primer 27F (5'AGAGTTTGATCMTGGCTCAG-3') and the Eubacterial-specific primer 1492R (5'-TACGGYTACCTTGTTACGACTT-3'; Weisburg et al. 1991). An initial $94^{\circ} \mathrm{C}$ denaturing step for $5 \mathrm{~min}$ was followed by 30 cycles of amplification ( 3 min denaturation at $94^{\circ} \mathrm{C}_{i} 1 \mathrm{~min}$ annealing starting at $65^{\circ} \mathrm{C}$ for the first cycle and reduced $0.5^{\circ} \mathrm{C}$ per cycle to $50^{\circ} ; 3 \mathrm{~min}$ extension at $72^{\circ} \mathrm{C}$ ), 5 addi- 
tional cycles of amplification $\left(3 \mathrm{~min}\right.$ at $94^{\circ} \mathrm{C}_{i} 1 \mathrm{~min}$ at $50^{\circ} \mathrm{C} ; 3 \mathrm{~min}$ at $72^{\circ} \mathrm{C}$ ) and a final extension of $10 \mathrm{~min}$ at $72^{\circ} \mathrm{C}$. The PCR products were separated by electrophoresis on a $0.8 \%$ agarose gel and stained with ethidium bromide for confirmation of $\sim 1460$ bp product.

Cell lysis and PCR amplification: natural assemblages. Seawater was collected off Scripps Pier (La Jolla) and Mission Bay (San Diego) in 11 acid-washed containers. In an attempt to disrupt particles and homogenize the sample, the water was forcefully hand shaken for $30 \mathrm{~s}$ and then gravity filtered through $3.0 \mu \mathrm{m}$ polycarbonate filter (Poretics). Parallel samples were taken for $1 \mu \mathrm{l}, 1 \mathrm{ml}$ and $1 \mathrm{l}$ extractions to examine the effect of sample volume and lysis protocols. Four replicate $1 \mu \mathrm{l}$ samples were transferred to $200 \mu \mathrm{l}$ PCR tubes, $5 \mu \mathrm{l}$ of Lyse-N-Go ${ }^{\mathrm{TM}}$ was added and the samples were stored at $-20^{\circ} \mathrm{C}$. Four replicate $1 \mathrm{ml}$ samples were pelleted at $23000 \times g$ for $20 \mathrm{~min}$ at $4^{\circ} \mathrm{C}$. The supernatant was aspirated and the pellet resuspended in $5 \mu \mathrm{l}$ of Lyse-N-Go ${ }^{\mathrm{TM}}$, then transferred to $200 \mu \mathrm{l}$ PCR tube and stored at $-20^{\circ} \mathrm{C}$. One liter of seawater was collected on a $0.22 \mu \mathrm{m}$ Sterivex capsule (Millipore) and DNA was extracted by the protocol of Somerville et al. (1989). Touchdown PCR amplification (described above) of a 170 to $192 \mathrm{bp}$ segment of the $16 \mathrm{~S}$ rRNA gene was conducted using a universal primer complementary to base positions 517 to 534 (5'-ATTACCGCGGCTGC TGG-3') and a eubacterial primer complementary to the base positions 341 to 358 with a $40 \mathrm{bp} \mathrm{GC}$ clamp (5'-CGCCCGCCGCGCGCGGCGGGCGGGGCGGGGGGCACGG GGGGCCTACCGGAGGCAGC-3'; Muyzer et al. 1993). Negative controls were run with sterile filtered water in place of template. PCR products were separated by electrophoresis on a $1.5 \%$ agarose gel and stained with ethidium bromide to confirm amplification of the desired product.

Denaturing gradient gel electrophoresis. The DGGE techniques and reagents used were a slight modification of Muyzer et al. (1993). Ten microliters of PCR product was loaded onto a $8 \%$ polyacrylamide gel (acrylamide- $N$ - $N$ '-methylene bisacrylamide [37:1]) in $0.5 \times$ TAE $\left(20 \mathrm{mM}\right.$ Tris, $10 \mathrm{mM}$ acetate, $0.5 \mathrm{mM} \mathrm{Na}_{2}$ EDTA, pH 8.2) with top to bottom denaturing gradient of 35 to $60 \%$ (with $100 \%$ denaturant being $40 \%$ [v/v] formamide and $7 \mathrm{M}$ urea). Electrophoresis was conducted at $10 \mathrm{~V} \mathrm{~cm}^{-1}$ for $5.5 \mathrm{~h}$ at $60^{\circ} \mathrm{C}$ in a hot-bath DGGE unit (CBS Scientific, San Diego, CA, USA) with a running buffer of $0.5 \times$ TAE. Gels were stained with $1 \times$ SYBR Green I in $0.5 \times$ TAE (Molecular Probes, Eugene, OR, USA) for $30 \mathrm{~min}$ in the dark, and then destained in $0.5 \times \mathrm{TAE}$ for $10 \mathrm{~min}$. The gels were then visualized and documented on a UVP Epi-chemi Darkroom with a charge coupled devide (CCD) camera. Images were integrated 4 to $14 \mathrm{~s}$, below the light saturation value for the most intense band on the gel.
For our study, we are considering each band as a phylotype (or as expressed by other authors, an 'operational taxonomic unit' or 'OTU'). While this assumption is not necessarily true, we agree with Ferrari \& Hollibaugh (1999) that this convention is useful in analysis of community banding patterns. In addition, we are treating the bands as bacterial phylotypes for the following 2 reasons: first, since $1 \mu \mathrm{l}$ samples are being investigated, the majority of the 16S rRNA gene copies would come from bacteria, although plastid DNA might be present if an algal cell was sampled. Second, we are using a primer that has been shown to be specific for Bacteria (Muyzer et al. 1993).

Cloning DGGE bands. DGGE bands were excised with sterile razor blades and placed in $2 \mathrm{ml}$ microcentrifuge tubes containing $400 \mu \mathrm{l}$ of $1 \times$ saline sodium citrate (SSC) buffer ( $0.6 \mathrm{M} \mathrm{NaCl}, 60 \mathrm{mM}$ trisodium citrate, $\mathrm{pH}$ 7) and eluted overnight at $37^{\circ} \mathrm{C}$. The acrylamide plugs were pelleted and the supernatant transferred to fresh tubes and precipitated with $1 / 10$ volume $10 \mathrm{M}$ $\mathrm{LiCl}$ and 3 volumes of $100 \%$ ethanol. The precipitate was resuspended in $10 \mu \mathrm{l}$ of filtered autoclaved Milli-Q water, and the DNA was cloned with a TOPO TA cloning kit (Invitrogen, Carlsbad, CA, USA) per manufacturer's instructions. Clones were screened for correct size insertions by PCR amplification using T7 and M13R primers, and those with the appropriate PCR products were reamplified with the DGGE primer set used above and analyzed by DGGE to confirm relative position of the cloned band with the original band.

Sequencing and phylogenetic analysis. Clones were sequenced using ABI PRISM BigDye dye-terminator chemistry (Perkin-Elmer) using M13R primer and an automated ABI DNA sequencer. Sequences were aligned to known sequences in the GenBank database using BLAST (Altschul et al. 1990). Phylogenetic relationships were inferred from multiple alignments using CLUSTAL W (Thompson et al. 1994) and neighbor-joining method of NJPlot.

Sampling for small-scale patchiness. A 11 seawater sample was taken $\sim 0.5 \mathrm{~m}$ below the sea surface off Scripps Pier and from it 8 sub-samples of $1 \mu \mathrm{l}$ seawater were taken $\sim 7$ to $8 \mathrm{~mm}$ below the surface. Each subsample was placed in a $200 \mu \mathrm{l}$ PCR tube with $5 \mu \mathrm{l}$ of Lyse- $\mathrm{N}-\mathrm{Go}^{\mathrm{TM}}$ and amplified as above in the community analysis. Two sterile $0.2 \mu \mathrm{m}$ filtered water blanks served as negative controls.

Effect of detritus enrichment. Seawater collected off Scripps Pier was enriched with a final concentration of 0 (control), 1 (low) or 10 (high) $\mathrm{\mu l}^{-1}$ freeze-thaw-killed Thalassiosira weissflogii cells (prepared as in Bidle \& Azam 1999; briefly, an axenic culture of T. weissflogii was harvested, washed and freeze-thawed $7 \times$ ). Diatom detritus was confirmed to be bacteria free, by epifluorescence microscopy (Noble \& Fuhrman 1998). Four 
initial samples were collected, and then all treatments were sampled at $5 \mathrm{~h}$ (based on our prior experience of the time course of colonization $T$. weissflogii by natural assemblages of bacteria; not shown)

Sampling for microscale patchiness. We made a 10capillary-tube sampling device to sample $1 \mu \mathrm{l}$ of seawater every $2 \mathrm{~mm}$ over a $20 \mathrm{~mm}$ linear 'transect.' The sampling device consisted of a microscope slide with $10 \times 1 \mu$ glass capillary tubes (Drummond Scientific, Broomall), spaced $1 \mathrm{~mm}$ apart and affixed with molding clay.

One liter samples were collected off Scripps Pier during the peak (11 July 2000) and at a later stage (14 July 2000) of a bloom of the dinoflagellate Lingulodinium polyedrum. Sub-samples were taken from 6 to $8 \mathrm{~mm}$ below the surface. Three additional capillaries were filled with sterile filtered water and processed in parallel as negative controls.

Data analysis. To compare samples from our 2 sampling sites, Scripps Pier and Mission Bay, a partitioning clustering method was used since we had a priori knowledge that 2 different communities were being analyzed. A Euclidian K-mean matrix was generated with the samples sorted into 2 clusters selected and the data were iterated 25 times in Statistica (V5.5.A; Statsoft, Tulsa, OK).

To assess patchiness, a hierarchical clustering method was used since we had no a priori knowledge of the numbers of clusters in each sample. From the DGGE images bands were electronically identified using Labworks software (UVP), with a minimum band size of $1 \%$ of the gel length (approximately 3 pixels). Multiple images of the DGGE with different integration times were used to compensate for the variation of signal between the lanes. To analyze samples for patchiness band-based comparisons were made using the Jaccard index of similarity (Ferrari \& Hollibaugh 1999). The Jaccard index $\left(S_{\mathrm{j}}\right)$ is calculated as follows $\left(n_{\mathrm{AB}}=\right.$ common bands in both lanes $A$ and $B_{;} n_{A}=$ bands in lane $A_{;}$ $n_{\mathrm{b}}=$ bands in lane B):

$$
S_{\mathrm{j}}=n_{\mathrm{AB}} /\left(n_{\mathrm{A}}+n_{\mathrm{b}}-n_{\mathrm{AB}}\right)
$$

Unweighed pair group average linkage rules were applied to the Jaccard index matrix to generate a dendrogram with Statistica.

\section{RESULTS}

\section{Effectiveness of Lyse-N-Go ${ }^{\mathrm{TM}}$ protocol}

To test that Lyse-N-Go ${ }^{\mathrm{TM}}$ can lyse diverse marine bacterial species and yield PCR amplifiable DNA, we tested 60 isolates from our culture collection with the Lyse-N-Go ${ }^{\mathrm{TM}}$ manufacturer's recommended protocol.

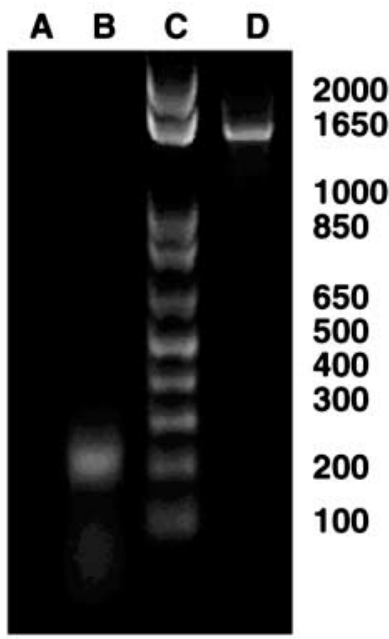

Fig. 1. Agarose gel separation of polymerase chain reaction (PCR) products. Bacterial samples were treated with Lyse-N-Go ${ }^{\mathrm{TM}}$ and segments of 16S rRNA gene were PCR amplified. (A) Negative control; (B) 341GC-534 PCR product; (C) $1 \mathrm{~kb}$ plus DNA ladder (Gibco BRL); (D) 27 1492 PCR product

The isolates covered a range of Gram-negative bacteria (e.g. Alteromonas, Vibrio, Roseobacter, Silicibacter and Flexibacter) and a few Gram-positive bacteria (Staphylococcus and Bacillus). For PCR-DGGE, we targeted a region of the $16 \mathrm{~S}$ rDNA gene that included the hypervariable V3 region in conjunction with a $40 \mathrm{bp}$ GC clamp. We obtained PCR products of the expected sizes ( 190 and $\sim 1460 \mathrm{bp})$ for all samples, as determined by agarose gel electrophoresis (Fig. 1).

\section{Effect of sample size}

We compared the Lyse-N-Go ${ }^{\mathrm{TM}}$ extraction protocol with standard methods (Fuhrman et al. 1988, Somerville et al. 1989), which involve extracting large volumes of seawater. We sampled varying volumes of shaken $3.0 \mu \mathrm{m}$ filtered seawater, from $1 \mu \mathrm{l}$ to $1 \mathrm{l}$, from Scripps Pier and treated them with the Lyse-N-Go ${ }^{\mathrm{TM}}$ protocol or a standard filtration and extraction protocol. The community banding patterns observed on DGGE between the replicates were nearly identical, as were the patterns for all sample sizes $(1 \mu \mathrm{l}, 1 \mathrm{ml}$, 1 l) for the 2 methods (Fig. 2). The dominant DGGE bands occupied the same position in all samples. Some minor bands were also identical in all samples (Fig. 2).

Mission Bay samples yielded DGGE profiles that were all similar, regardless of the collection and extraction protocol (Fig. 2). Comparison of Scripps Pier and Mission Bay samples confirmed that the banding patterns were not a PCR-DGGE artifact. Visual comparison of DGGE patterns between samples from the 2 sites showed some common bands but also differences in the bacterial assemblage composition (Fig. 2). Partitioning cluster analysis also confirmed similarity with samples from the same site but differences between sites (Table 1). We had loaded sample S4 twice on the 


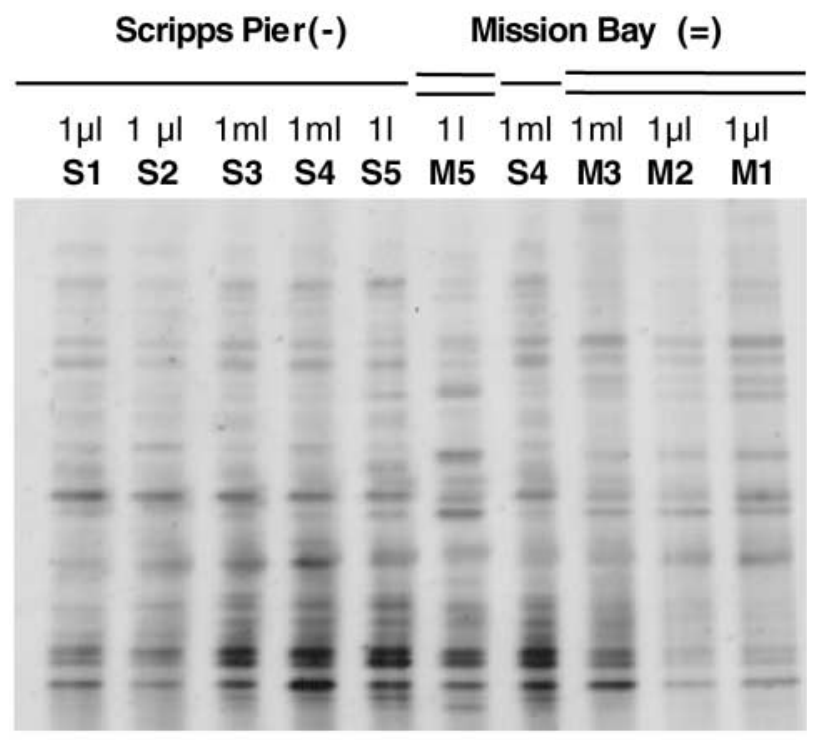

Fig. 2. Comparison of different sample sizes, extraction methods and bacterial community by PCR-denaturing gradient gel electrophoresis (DGGE). Samples were collected from Scripps Pier (S) and Mission (M), California, USA. The Lyse$\mathrm{N}-\mathrm{Go}^{\mathrm{TM}}$ PCR protocol (S1, S2, S3, S4, M1, M2 and M3) was compared with the Sterivex collection and extraction method (S5 and M5). The image was captured with a digital camera and inverted with Photoshop (Adobe)

gel (Fig. 2) to test if slight variations within the DGGE would affect the cluster analysis; we observed both samples clustering together in the SIO group. Thus, the Lyse-N-Go ${ }^{\mathrm{TM}}$ protocol was at least as effective as the standard protocol.

\section{Small-scale patchiness}

We tested for small-scale patchiness of bacterial species composition on parallel samples that were either left untreated or homogenized (by shaking and

Table 1. Cluster analysis of bacterial community similarity based on polymerase chain reaction/denaturing gradient gel electrophoresis (PCR-DGGE). Lanes from Fig. 2 were compared for relationships by Euclidian K-means clustering analysis for 2 groups with 25 iterations. MB: Mission Bay; SIO: Scripps Pier

\begin{tabular}{|ll|}
\hline Group 1 & Group 2 \\
\hline MB 1 l (M5) & SIO $1 \mu \mathrm{l}(\mathrm{S} 1)$ \\
MB $1 \mathrm{ml}(\mathrm{M} 3)$ & SIO $1 \mu \mathrm{l} 2)$ \\
MB $1 \mu \mathrm{M} 1)$ & SIO $1 \mathrm{ml}(\mathrm{S} 4)$ \\
MB $1 \mu \mathrm{l}(\mathrm{M} 2)$ & SIO $1 \mathrm{ml}(\mathrm{S} 4)$ \\
& SIO 11 (S5) \\
& SIO $1 \mathrm{ml}(\mathrm{S} 3)$ \\
\hline
\end{tabular}

filtering through $3 \mu \mathrm{m}$ filter) seawater samples. At the $1 \mu \mathrm{l}$ scale, we found patchiness of bacterial species distribution by DGGE (Fig. 3A, most notably in sample $H$ ). In fact, in unperturbed samples, no two lanes had identical banding patterns (Fig. 3A). Only 7 of 22 detectable bands or phylotypes were present in all 8 samples, while 12 of 22 phylotypes were found in $\geq 6$ samples. Five unique phylotypes were detected, 3 in a single sample (labeled $\mathrm{H}$ in Fig. 3A), which, as seen by cluster analysis (Fig. 3B), is the most distinct of all sub-samples. Unique phylotypes were also present in samples B and D. We found 11 to 17 phylotypes per sample with a mean of 14 (Table 2). Thus, sampling at the microliter scale showed both ubiquitous and unique phylotype distributions.

\section{Effect of detritus enrichment}

To test that increased particle load causes enhanced species patchiness, we amended seawater with freeze-thawed Thalassiosira weissflogii cells. DGGE analysis of $1 \mu \mathrm{l}$ sub-samples indicated that there was greater patchiness in the high $\left(10\right.$ cell $\left.\mu^{-1}\right)$ treatments (Fig. 4A). There was a mean of 21, 21, 24 and 20 phylotypes for the initial, control, low and high treatments, respectively (Table 2). DGGE showed 4 ubiquitous phylotypes out of 32 detected, and 4 more were common in 13 of the 14 samples. Fifteen phylotypes were common in 10 or more samples. No unique phylotypes were detected, and 2 were common in only 2 samples (initial and control; control and high). Cluster analysis showed that the unamended samples remained similar to the initial samples, but detritusenriched samples showed greater dissimilarity (Fig. 4B). Thus, particle load enhancement led to increased species richness.

Table 2. Comparison of bacterial species richness. Phylotypes detected by PCR-DGGE in $1 \mu \mathrm{l}$ samples. Random samples, diatom detrius enrichment, transects during the peak and decline of a bloom of Lingulodinium polyhedra

\begin{tabular}{|c|c|c|c|c|c|c|}
\hline Samples & $\mathrm{N}$ & Total bands & Low & High & Mean & $\mathrm{SD}$ \\
\hline SIO Pier & 8 & 28 & 13 & 20 & 17 & 2.3 \\
\hline SIO enrichment & 14 & 36 & 17 & 25 & 22 & 2.8 \\
\hline Initial & 3 & 30 & 18 & 24 & 21 & 3.1 \\
\hline Control & 4 & 35 & 20 & 22 & 21 & 1.0 \\
\hline Low enrichment & 4 & 33 & 23 & 25 & 24 & 1.0 \\
\hline High enrichment & 3 & 35 & 17 & 25 & 20 & 4.2 \\
\hline SIO bloom T1 & 10 & 52 & 16 & 38 & 28 & 7.1 \\
\hline SIO bloom T2 & 10 & 51 & 23 & 38 & 32 & 5.9 \\
\hline SIO bloom T3 & 10 & 46 & 18 & 34 & 28 & 6.5 \\
\hline SIO post bloom & 10 & 34 & 9 & 19 & 12 & 2.8 \\
\hline
\end{tabular}



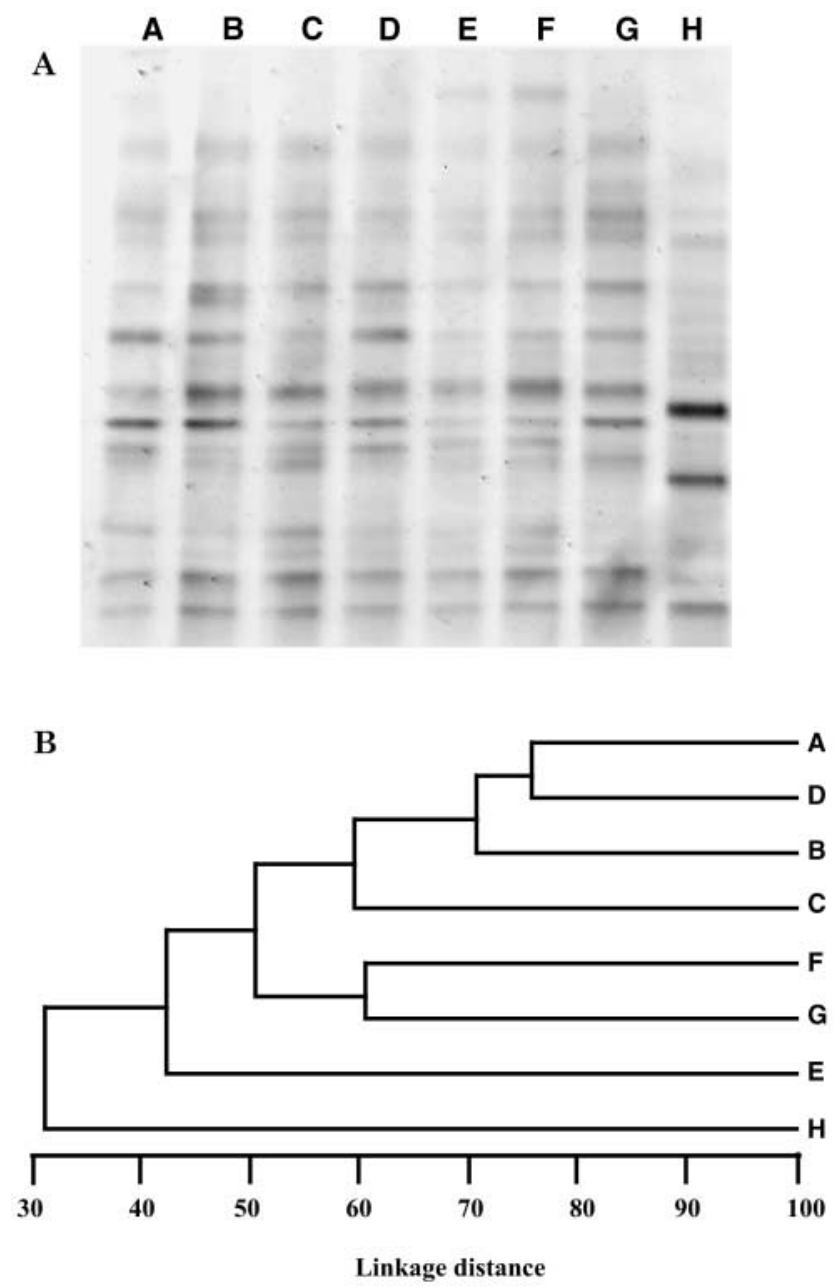

Fig. 3. Small-scale bacterial species patchiness. (A) PCRDGGE analysis of $1 \mu \mathrm{l}$ sub-samples taken from $1 \mathrm{l}$ of seawater collected off Scripps Pier were analyzed with the Lyse-N$\mathrm{Go}^{\mathrm{TM}}$ PCR-DGGE protocol. The gel image was collected with digital camera and inverted in Photoshop. (B) Cluster analysis dendrogram of natural bacterial genetic patchiness. The tree was constructed by applying unweighted pair group average linkage rules on a Jaccard index of similarity matrix calculated from the gel image

\section{Species richness and patchiness during and following a dinoflagellate bloom}

Using our capillary sampler we sampled a $20 \mathrm{~mm}$ transect for microscale patchiness during a Lingulodinium polyedrum bloom. Samples collected on 11 July 2000 (peak) and 14 July 2000 (post bloom) had 580 and 90 L. polyedrum $\mathrm{ml}^{-1}$, respectively (P. Vondassow \& E. Frame pers. comm.). DGGE analysis of 3 transects taken during the peak of the bloom showed patchiness and variability of phylotypes between samples (Fig. 5A). Up to 52 phlyotypes were observed per transect, while individual microliter samples contained between 16
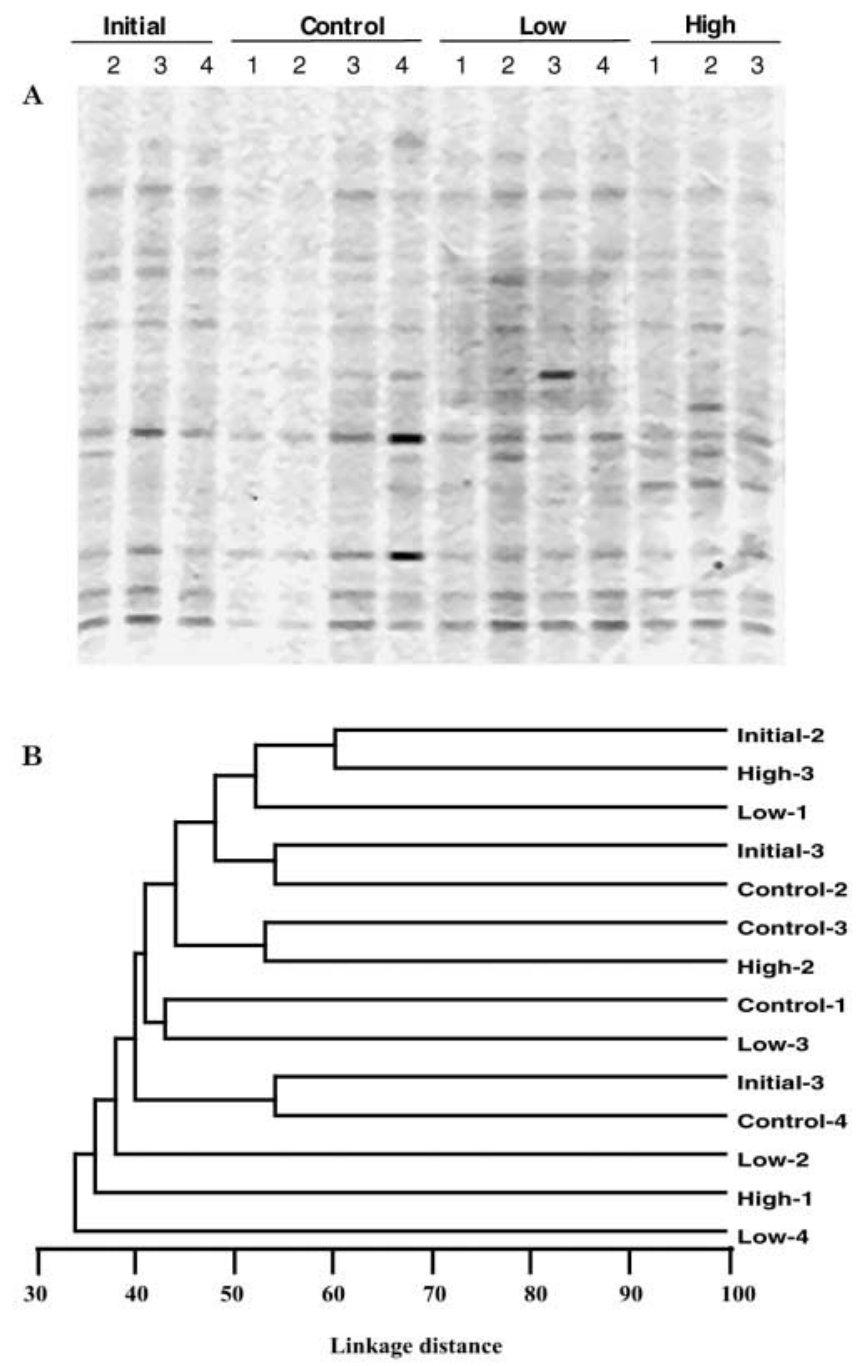

Fig. 4. Bacterial response to enrichment. Analysis of induced bacterial species patchiness. Seawater was amended with 1 or 10 detrital Thalassiosira weissflogii cells $\mu^{-1}$ and incubated for $5 \mathrm{~h}$. Samples were taken for initial bacterial species richness (initial), unamended seawater $5 \mathrm{~h}$ (control), amended with $1 \mathrm{~T}$. weissflogii cells $\mu^{-1}$ (low) and amended with $10 \mathrm{~T}$. weissflogii cells ${\mu l^{-1}}^{-1}$ high). Sub-samples were lysed using the Lyse-N-Go ${ }^{\mathrm{TM}}$ protocol and then (A) PCR-DGGE analysis. Samples initial-lane 1 and high-lane 4 were not used in further analysis. The image was captured with a digital camera and inverted in Photoshop. (B) Cluster analysis dendrogram of induced small-scale bacterial genetic patchiness. The tree was constructed by applying unweighted pair group average linkage rules on a Jaccard index of similarity matrix calculated from the gel image

and 38 phylotypes (Table 2). In all the transects there were at least 3 ubiquitous phylotypes. In one transect, we detected 3 unique phlyotypes, or bands present in a single sample. In another transect, one common phylotype was detected in samples that were taken $14 \mathrm{~mm}$ apart, but not in between. One phylotype detected in 9 of the samples was absent in an interior sample of the 


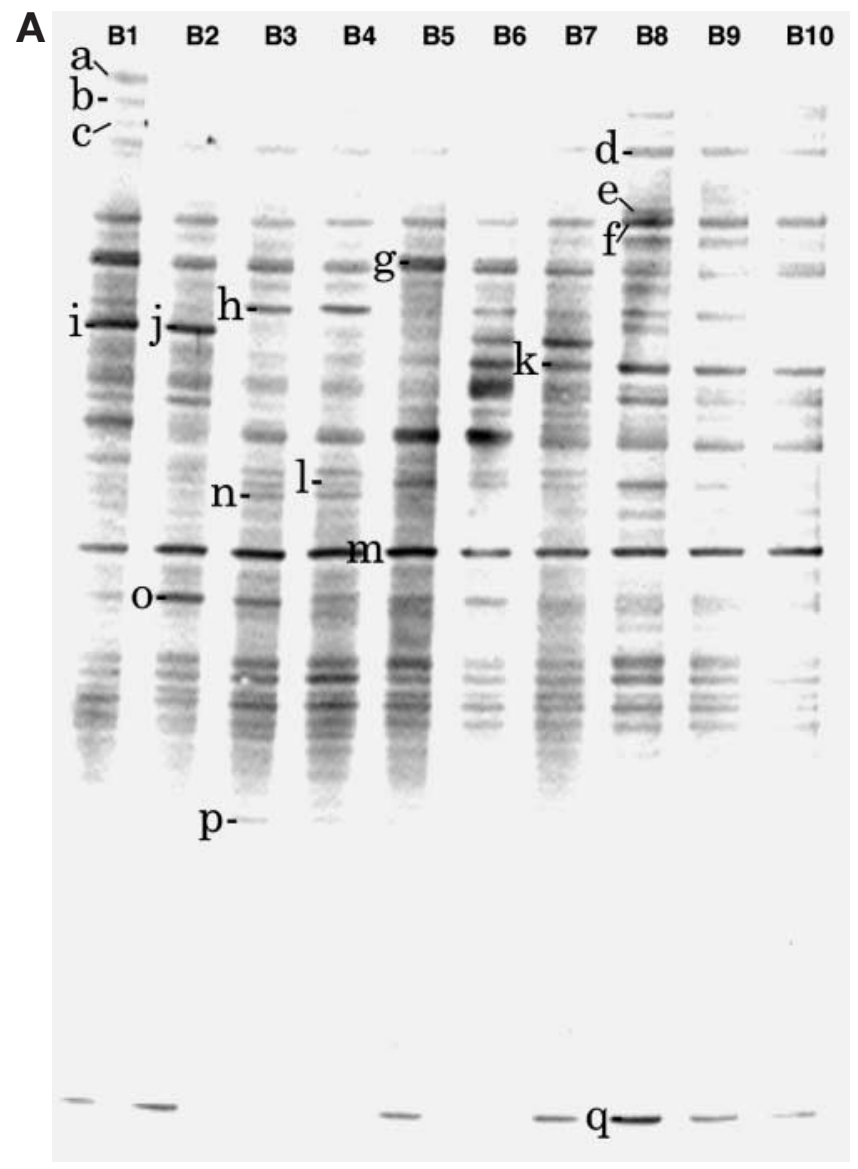

Fig. 5. Analysis of microscale bacterial species patchiness during a bloom of Lingulodinium polyedrum. Ten $1 \mu \mathrm{l}$ samples were taken $2 \mathrm{~mm}$ apart. Samples were treated with the Lyse-N-Go ${ }^{\mathrm{TM}}$ protocol and analysed by (A) PCR-DGGE. The image was captured with a digital camera and inverted in Photoshop. (B) Cluster analysis dendrogram of microscale bacterial genetic patchiness. The tree was constructed by applying unweighted pair group average linkage rules on a Jaccard index of similarity matrix calculated from the gel image. (C) Phylogenetic analysis of bands from the DGGE gel. Similarity based upon BLAST search of GenBank database

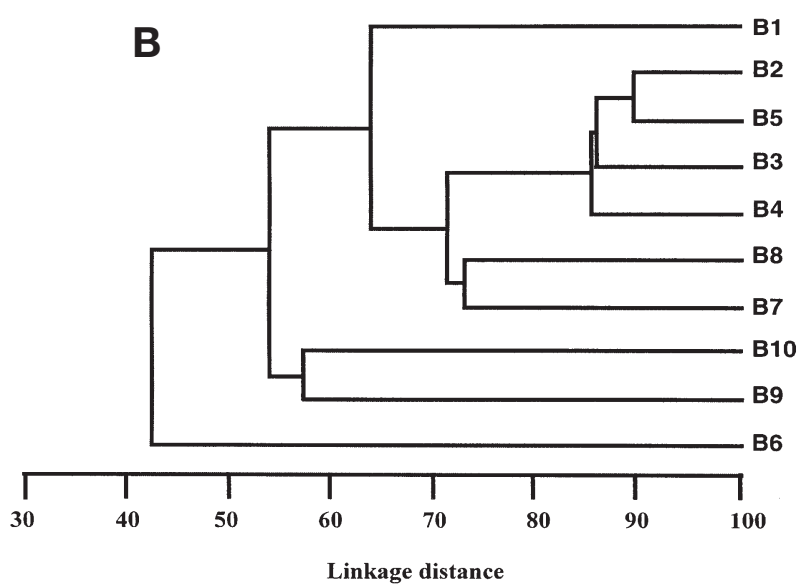

\begin{tabular}{|c|c|c|c|c|}
\hline Fig ID & Closest relative & Similarity & Accession & Taxon \\
\hline a & Uncultured bacterium (G3) & 96 & AB027628 & $\varepsilon$-Proteobacteria \\
\hline b & Comamonas acidovorans, Rape rhizosphere & 99 & AF1 49849 & $\beta$-Proteobacteria \\
\hline c & Sulfitobacter sp. (GAl-21) & 92 & AF007257 & $\alpha$-Proteobacteria \\
\hline d & Uncultured marine bacterium (SK1) & 98 & AB035011 & Sphingobacteria \\
\hline e & Rape rhizosphere bacterium (tsb077) & 96 & AJ295454 & $\beta$-Proteobacteria \\
\hline $\mathrm{f}$ & Unidentified beta proteobacterium (OM43) & 91 & U70704 & $\beta$-Proteobacteria \\
\hline g & Comamonas acidovorans, Rape rhizosphere & 98 & AF1 49849 & $\beta$-Proteobacteria \\
\hline $\mathrm{h}$ & Uncultured bacterium & 100 & AFO 91516 & Eubacteria \\
\hline $\mathrm{i}$ & Rape rhizosphere bacterium (tsb068) & 98 & AJ295450 & $\beta$-Proteobacteria \\
\hline j & Rape rhizosphere bacterium (tsb068) & 98 & AJ295450 & $\beta$-Proteobacteria \\
\hline $\mathrm{k}$ & Pseudomonas aeruginosa & 100 & AF298837 & $\gamma$-Proteobacteria \\
\hline I & Unidentified bacterium (HRV4\# HpaAS2) & 99 & UBZ88582 & $\alpha$-Proteobacteria \\
\hline $\mathrm{m}$ & Unidentified bacterium (C7) & 90 & BSPZ77471 & Sphingobacteria \\
\hline & Environmental Clone (OCS 162) & 82 & AF001 659 & Chloroplast \\
\hline $\mathrm{n}$ & Aquaspirillum gracile, etc & 100 & AF078753 & $\beta$-Proteobacteria \\
\hline o & Pseudomonas & 99 & AF307873 & $\gamma$-Proteobacteria \\
\hline & Uncultured alpha proteobactium (NAC11-16) & 99 & AF245641 & $\alpha$-Proteobacteria \\
\hline $\mathrm{p}$ & Klebsiella planticola & 100 & AB004755 & $\gamma$-Proteobacteria \\
\hline$q$ & Propionibacterium acnes (1477) & 100 & AB041617 & Actinobacteria \\
\hline
\end{tabular}

*Highest similarity from a BLAST search of the GenBank database

same transect. Gradients were observed such that several phylotypes were present in the first part of the transect, but not in the later portions, or vice versa. Patchy distribution of species was reflected in the cluster analysis (Fig. 5B), often high levels of dissimilarity being detected between the samples within transects.
We cloned and sequenced bands from a DGGE representing one transect taken during the bloom. Results revealed a diverse population that included members of the Proteobacteria $(\alpha, \beta, \varepsilon$ and $\gamma)$, Actinobacteria and Sphingobacteria groups. However, we were unable to obtain sequences for all the excised bands. Few bands 


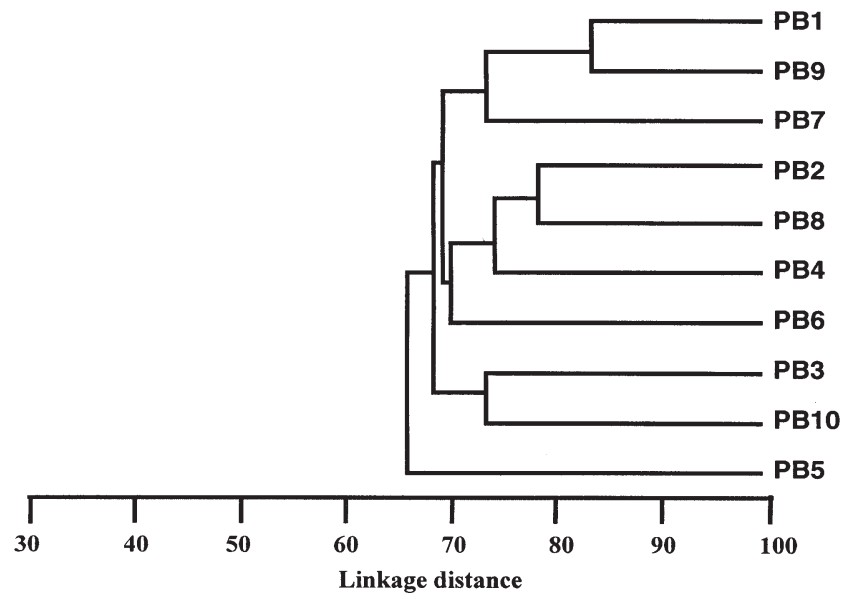

Fig. 6. Cluster analysis of microscale bacterial species patchiness in the latter stage a bloom of Lingulodinium polyedrum. Ten $1 \mu \mathrm{l}$ samples were taken $2 \mathrm{~mm}$ apart. Samples were treated with the Lyse-N-Go ${ }^{\mathrm{TM}}$ protocol and analyzed by PCRDGGE. The dendrogram was constructed by applying unweighted pair group average linkage rules on a Jaccard index of similarity matrix calculated from the gel image

were unique to a single sample, e.g. Fig. 5 lane B2 band ' $\mathrm{p}$ ' and lane B1 band 'a' representing a Klebsiella and an $\varepsilon$-Proteobacteria. Two ubiquitous bands among those sequenced were representatives of the $\beta$ Proteobacteria and a second band that represented a Sphingobacteria and chloroplast.

DGGE analysis of post bloom samples also showed patchiness (data not shown), and cluster analysis showed high levels of dissimilarity (up to $35 \%$; Fig. 6). Species richness was lower in post bloom samples, with 34 total phylotypes and a mean of 12 (Table 2). One ubiquitous phylotype and 5 unique phylotypes were identified. Twenty of the 34 phylotypes were found in 3 or fewer samples, and the majority of these were in non-adjacent samples. Comparison between the transects indicated greater bacterial species rich- ness and patchiness during the peak of the bloom than in the post bloom stage (Fig. 7).

\section{DISCUSSION}

\section{Methodology and its utility}

Current techniques for assessing bacterial community composition typically rely on collecting and filtering 1 to 101 seawater followed by a lysis and extraction protocol (e.g. Fuhrman et al. 1988, Somerville et al. 1989). Both steps are laborious and logistically limit the number of samples collected and processed. Our study shows the applicability of Lyse-n-Go ${ }^{\mathrm{TM}}$ for rapid, inexpensive and efficient extraction of pelagic bacterial community DNA ready for PCR amplification (indeed, already in the PCR tube) and analysis. The ease of sampling should enable studies with greater spatial, as well as temporal, resolutions. While we used the method to study microscale patchiness, it should also be applicable to ocean basin-scale studies. Since the method is simple and rapid it would be practical to do depth profiles and transects for species richness and diversity with sampling density comparable to bacterial counts. DGGE also lends itself to rapidly processing many samples. Further, high through-put sequencing is now more accessible to microbial oceanographers, making it practical and affordable to sequence all discernible DGGE bands. Thus, the protocol used here should enable studies of spatial-temporal variations in bacterial species richness and community composition not only at the microscale but also at larger scales in the contexts of bacterial biogeochemistry and biogeography. Future, biological oceanographic cruises involving hydrocasts might routinely extract and freeze microliter samples for 'posterity'. Investment in time (and hydrocast volume fraction!) being trivial, libraries of global ocean-scale environmental bacterial DNA

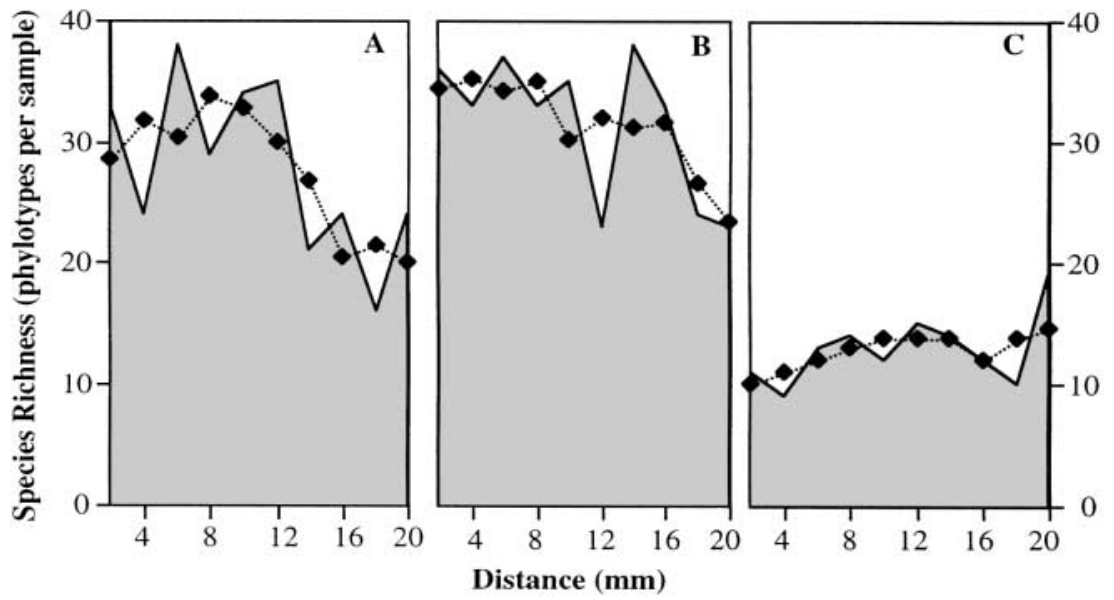

Fig. 7. Microscale variability of bacterial species richness. Ten $1 \mu \mathrm{l}$ samples taken $2 \mathrm{~mm}$ apart were examined for species richness $(\square)$ by Lyse-N-Go ${ }^{\mathrm{TM}}$ PCRDGGE. In addition a 3 point moving mean $(\diamond)$ is presented for samples taken on (A,B) 11 July 2000, the peak of Lingulodinium polyedrum bloom; (C) 14 July 2000 , the decline of the bloom 
(and perhaps viral DNA as well, although this may require protocol modification) could be archived for future analyses. For such archival purposes larger $(1 \mathrm{ml})$ samples might be pelleted and then extracted with Lyse-N-Go ${ }^{\mathrm{TM}}$, aliquoted and kept at $-80^{\circ} \mathrm{C}$.

The Lyse-N-Go ${ }^{\mathrm{TM}}$ method might also be applicable to bacterial assemblages on individual marine particles. We have successfully applied it to individual marine snow aggregates (Long \& Azam unpubl.). It might also be applicable to individual particles from sediments (and soil) but this was not tested. However, care should be taken to prevent contamination of reagents, as small target numbers are being amplified.

The sensitivity of PCR-DGGE for detecting a specific phylotype has been estimated to be $1 \%$ (Muyzer et al. 1993) and 1.6\% (Murray et al. 1996) of the assemblage. By sampling and analyzing multiple microliter samples in patchy environments one might be able to 'lower' the detection level for rare phylotypes by 'hitting hot spots' where these species may represent a larger proportion of the assemblage than in bulk water. Indeed, sequencing of the millimeter-scale transect samples during the bloom revealed such instances. One band was only present in a single sample, an $\varepsilon$-Proteobacteria (Fig. 5, band A). In 16S rDNA studies, this group is rarely found in pelagic samples, having been reported only during enrichments, e.g. during a brown tide bloom of Aureococcus anophagefferens (Kelly \& Chistoserdov 2001) and in a mesocosm diatom bloom (Riemann et al. 2000). However, we did not determine if this phylotype would have been missed in a multi-liter sample. The method is applicable not only to obtaining relatively small length PCR products used in DGGE analysis but also for amplifying larger segments of the 16S rDNA. Therefore, the protocol could be used for construction of clone libraries of natural samples as well as other PCR amplification techniques.

\section{Variation in species richness and composition}

The species richness (Fig. 7) and diversity in our $1 \mu \mathrm{l}$ samples (Figs 2, $3 \&$ \& A) was comparable to that in earlier studies in California coastal waters using large samples (Murray et al. 1996, Hollibaugh et al. 2000) and including sampling during a Lingulodinium polyedrum bloom (Fandino et al. 2001). Previous studies off Scripps Pier typically found bacterioplankton from the $\alpha$ - and $\gamma$-Proteobacteria and Sphingobacteria to be common (Pinhassi et al. 1999, Riemann et al. 2000, Fandino et al. 2001). While our samples included representatives from those taxa, they also contained a high proportion of $\beta$-Proteobacteria closely related, phylogenetically, to bacterial isolates from the rhizosphere of Brassica napus, a Swedish turnip plant. While physiological similarity cannot reliably be inferred from 16S rDNA-based phylogenetic relatedness, it might be interesting to examine whether our $\beta$-Proteobacteria phylotypes form symbioses with plankton or show adaptations to enriched microniches. Further, one ubiquitous phylotype was a Sphingobacteria that was related to a large fraction of phylotypes in the dinoflagellate bloom study by Fandino et al. (2001).

\section{Causes of spatial variations in species richness}

It is axiomatic that bacteria live in microenvironments. However, we do not know how generally important microenvironments are for the ecology of pelagic bacteria (i.e. do microenvironments matter only for rare individuals and such as marine snowassociated bacteria?). Technical difficulties have precluded studies of the nature, spatial-temporal scales and variability of relevant microenvironmental parameters, e.g. nutrient, effector and predator fields experienced by individual bacteria. Earlier studies (Bell \& Mitchell 1972, Azam \& Ammerman 1984, De Long et al. 1993) considered low abundance loci of organic matter (e.g. phytoplankton, dead plankton and marine snow; $10^{2}$ to $10^{3} \mathrm{ml}^{-1}$ ) as potentially creating organically enriched microzones for bacterial response. A greater abundance $\left(10^{3}\right.$ to $\left.10^{8} \mathrm{ml}^{-1}\right)$ of organic loci is indicated by discoveries of diverse 'transparent particles' (Koike et al. 1990, Wells \& Goldberg 1991, Alldredge et al. 1993, Moustajir et al. 1995, Long \& Azam 1996). Further, it has been speculated (Azam et al. 1993) and demonstrated (Chin et al. 1998) that some pelagic organic polymers, colloids and transparent particles exist as hydrogels. Thus, organic surfaces for bacterial interactions may be highly abundant and heterogeneous. Consequently, distinct microenvironments for bacteria may not be a rare feature of the pelagic realm, and species-specific responses of bacteria to them may cause variation in species richness at the microscale at high spatial frequency. While the knowledge on this problem is still rudimentary, our finding of variation in bacterial species richness at the millimeter scale, and enhancement of variation by particles, is consistent with this hypothesis.

Microscale patchiness of organic matter is only one of the many factors with the potential to cause spatial variations in bacterial species richness. Other factors are as follows: (1) Bacterial chemokinesis may be an important variable, even a pre-requisite, for bacterial occupation of a microniche. (2) Allelopathy was found to be common among bacterial isolates from southern California coastal waters; $\sim 1 / 2$ of the 86 tested isolates inhibited at least 1 (and up to 42) other isolate (Long \& Azam 2001). Long et al. (2000) showed that the in- 
clusion of an antibiotic (produced by a marine Alteromonas) in an agar 'model particle' altered the structure of the developing bacterial community on the particle. Thus, bacteria may cause species variations in their microniche by producing antibiotics. (3) Differential predation on different species of bacteria (by protozoa, phage and Bdellovibrio) could further influence species richness and diversity (Hennes et al. 1995, Jürgens et al. 1999). (4) The existence of distinct bacterial consortia in seawater, while not demonstrated, offers another possible explanation for microscale heterogeneity in species richness and diversity. (5) Symbiotic or mutualistic relationships of bacteria with phytoplankton could favor certain bacteria in a specific microenvironment.

\section{Ecological and biogeochemical implications}

Specific microenvironments may harbor species not capable of persistence in bulk phase conditions. However, upon changes in environmental conditions (e.g. phytoplankton bloom or water column destratification) these 'minor' species may seed the newly established bulk water and become abundant. Pinhassi et al. (1999) amended seawater in mesocosms with protein and found that 5 phylotypes rapidly rose from low densities to become dominant. In a mesocosm bloom study (Riemann et al. 2000) phylotypes undetectable during the first week became major in the second week (paralleling increased concentration of particulate organic carbon). Microscale hot spots (plankton surfaces) have also been suggested as harboring pathogenic bacteria in the sea (Colwell 1996).

In conclusion, we have shown the validity of a method for studying microscale variations in species richness and diversity and demonstrated its utility in pelagic samples. Our observations so far are limited, but they are consistent with the hypothesis of spatial variation of bacteria species richness and diversity at the microscale in seawater. Such patchiness, if supported by further study, would have implications for bacterial ecophysiology and oceanic biogeochemistry. Variations in species richness and diversity at the scale of $1 \mu \mathrm{l}$ of seawater, as seen here, allow for different types and intensities of biogeochemical transformations to occur from one 'drop' to another 'drop' of seawater. Several lines of evidence show that microbial processes at the small scale have consequences for ocean basin-scale biogeochemistry.

Acknowledgements. We thank N. Knowlton for the use of the UVP Epi-chemi Darkroom and Labworks software and K. Smith for use of PCR clean laboratory space. We acknowledge F. Rohwer and L. Aluwihare for comments on an earlier ver- sion of the manuscript as well as 2 anonymous reviewers and J. T. Hollibaugh for advice on data analysis. This work was supported by grants NSF OCE-9819603 and NIH(NIAID) A146600 to F.A.

\section{LITERATURE CITED}

Alldredge AL, Passow U, Logan BE (1993) The abundance and significance of a class of large, transparent organic particles in the ocean. Deep-Sea Res Part A 40:1131-1140

Altschul SF, Gish W, Miller W, Myers EW, Lipman DJ (1990) Basic local alignment search tool. J Mol Biol 215:403-410

Azam F (1998) Microbial control of oceanic carbon flux: the plot thickens. Science 280:694-696

Azam F, Ammerman JW (1984) Cycling of organic matter by bacterioplankton in pelagic marine ecosystems: microenvironmental considerations. In: Fasham MJR (ed) Flows of energy and materials in marine ecosystems. Plenum Publishing, New York, p 345-360

Azam F, Smith DC, Steward GF, Hagström Å (1993) Bacteriaorganic matter coupling and its significance for oceanic carbon cycling. Microb Ecol 28:167-179

Bell WH, Mitchell R (1972) Chemotactic and growth responses of marine bacteria to algal extracellular products. Biol Bull 143:265-277

Biddanda BA, Pomeroy LR (1988) Microbial aggregation and degradation of phytoplankton-derived detritus in seawater. I. Microbial succession. Mar Ecol Prog Ser 42:79-88

Bidle KD, Azam F (1999) Accelerated dissolution of diatom silica by marine bacterial assemblages. Nature 397:508-512

Blackburn N, Fenchel T, Mitchell J (1998) Microscale nutrient patches in planktonic habitats shown by chemotactic bacteria. Science 282:2254-2256

Chin WC, Orellana MV, Verdugo P (1998) Spontaneous assembly of marine dissolved organic matter into polymer gels. Nature 391:568-572

Cho BC, Azam F (1988) Major role of bacteria in biogeochemical fluxes in the ocean's interior. Nature 332:441-443

Cole JJ, Findlay S, Pace ML (1988) Bacterioplankton production in fresh and saltwater ecosystems: a cross-system overview. Mar Ecol Prog Ser 43:1-10

Colwell RR (1996) Global climate and infectious disease: the cholera paradigm. Science 274:2025-2031

del Giorgio PA, Cole JJ (1998) Bacterial growth efficiency in natural aquatic systems. Annu Rev Ecol Syst 29:503-541

De Long EF, Franks DG, Alldredge AL (1993) Phylogenetic diversity of aggregate-attached vs free-living marine bacterial assemblages. Limnol Oceanogr 38:924-934

Don RH, Cox PT, Wainwright BJ, Baker K, Mattick JS (1991) 'Touchdown' PCR to circumvent spurious priming during gene amplification. Nucleic Acids Res 19:4008

Duarte CM, Vaque D (1992) Scale dependence of bacterioplankton patchiness. Mar Ecol Prog Ser 84:95-100

Ducklow HW, Fasham MJR (1992) Bacteria in the greenhouse: modeling the role of oceanic plankton in the global carbon cycle. In: Mitchell R (ed) Environmental microbiology. Wiley-Liss, New York, p 1-31

Fandino LB, Riemann L, Steward GF, Long RA, Azam F (2001) Variations in bacterial community structure during a dinoflagellate bloom analyzed by DGGE and rDNA sequencing. Aquat Microb Ecol 23:119-130

Ferrari VC, Hollibaugh JT (1999) Distribution of microbial assemblages in the central Arctic Ocean Basin studied by PCR/DGGE: analysis of a large data set. Hydrobiologia 401:55-68

Fuhrman JA, Comeau DE, Hagström ^, Chan AM (1988) 
Extraction From natural planktonic microorganisms of DNA suitable for molecular biological studies. Appl Environ Microbiol 54:1426-1429

Giovannoni S, Rappè M (2000) Evolution, diversity, and molecular ecology of marine prokaryotes. In: Kirchman DL (ed) Microbial ecology of the oceans. Wiley-Liss, New York, p 47-84

Hennes KP, Suttle CA, Chan AM (1995) Fluorescently labeled virus probes show that natural virus populations can control the structure of marine microbial communities. Appl Environ Microbiol 61:3623-3627

Hollibaugh JT, Wong PS, Murrell MC (2000) Similarity of particle-associated and free-living bacterial communities in northern San Francisco Bay, California. Aquat Microb Ecol 21:103-114

Jürgens K, Pernthaler J, Schalla S, Amann R (1999) Morphological and compositional changes in a planktonic bacterial community in response to enhanced protozoan grazing. Appl Environ Microbiol 65:1241-1250

Kelly KM, Chistoserdov AY (2001) Phylogenetic analysis of the succession of bacterial communities in the Great South Bay (Long Island). FEMS Microbiol Ecol 35:85-95

Koike I, Shigemitsu H, Kazuki T, Kogure K (1990) Role of submicrometre particles in the ocean. Nature 345:242-244

Long RA, Azam F (1996) Abundant protein-containing particles in the sea. Aquat Microb Ecol 10:213-221

Long RA, Azam F (2001) Antagonistic interactions amongst marine pelagic bacteria. Appl Environ Microbiol 67: 4975-4983

Long RA, Qureshi A, Faulkner DJ, Azam F (2000) A Quinolinol antibiotic produced by a marine Alteromonad affects physiology and metabolism of other marine bacteria. American Society of Limnology and Oceanography Copenhagen, June 8, 2000. SS10-04

Mitchell JG, Fuhrman JA (1989) Centimeter scale vertical heterogeneity in bacteria and chlorophyll a. Mar Ecol Prog Ser 54:141-148

Mitchell JG, Pearson L, Dillon S (1996) Clustering of marine bacteria in seawater enrichments. Appl Environ Microbiol 62:3716-3721

Mostajir B, Dolan JR, Rassoulzadegan F (1995) A simple method for the quantification of a class of labile marine pico- and nano-sized detritus: Dapi Yellow Particles (DYP). Aquat Microb Ecol 9:259-266

Muller-Niklas G, Agis M, Herndl GJ (1996) Microscale distribution of bacterioplankton in relation to phytoplank-

Editorial responsibility: James Hollibaugh,

Athens, Georgia, USA ton: results from 100-nL samples. Limnol Oceanogr 41: $1577-1582$

Murray AE, Hollibaugh JT, Orrego C (1996) Phylogenetic compositions of bacterioplankton from two California estuaries compared by denaturing gradient gel electrophoresis of 16S rDNA fragments. Appl Environ Microbiol 62:2676-2680

Muyzer G, Dewaal EC, Uitterlinden AG (1993) Profiling of complex microbial populations by denaturing gradient gel electrophoresis analysis of polymerase chain reactionamplified genes coding for 16S rRNA. Appl Environ Microbiol 59:695-700

Noble RT, Fuhrman JA (1998) Use of SYBR Green I for rapid epifluorescence counts of marine viruses and bacteria. Aquat Microb Ecol 14:113-118

Pinhassi J, Azam F, Hemphala J, Long RA, Martinez J, Zweifel UL, Hagström $\AA$ (1999) Coupling between bacterioplankton species composition, population dynamics, and organic matter degradation. Aquat Microb Ecol 17:13-26

Riemann L, Steward GF, Azam F (2000) Dynamics of bacterial community composition and activity during a mesocosm diatom bloom. Appl Environ Microbiol 66:578-587

Seymour JR, Mitchell JG, Pearson L, Waters RL (2000) Heterogeneity in bacterioplankton abundance from 4.5 millimetre resolution sampling. Aquat Microb Ecol 22:143-153

Smith DC, Steward GF, Long RA, Azam F (1995) Bacterial mediation of carbon fluxes during a diatom bloom in a mesocosm. Deep-Sea Res Part B 42:75-97

Somerville CC, Knight IT, Straube WL, Colwell RR (1989) Simple, rapid method for direct isolation of nucleic acids from aquatic environments. Appl Environ Microbiol 55: $548-554$

Thompson JD, Higgins, DG, Gibson, TG (1994) CLUSTAL W: improving the sensitivity of progressive multiple sequence alignment through sequence weighting, position-specific gap penalties and weight matrix choice. Nucleic Acids Res 22:4673-4680

Turley CM, Stutt ED (2000) Depth-related cell-specific bacterial leucine incorporation rates on particles and its biogeochemical significance in the Northwest Mediterranean. Limnol Oceanogr 45:419-425

Weisburg WG, Barns SM, Pelletier DA, Lane DJ (1991) 16s Ribosomal DNA amplification for phylogenetic study. J Bacteriol 173:697-703

Wells ML, Goldberg ED (1991) Occurrence of small colloids in sea water. Nature 353:342-344

Submitted: August 14, 2000; Accepted: September 18, 2001 Proofs received from author(s): November 19, 2001 